\title{
Factors Affecting Post-Harvest Life of Flower Crops
}

\author{
Jagreeti Gupta* and R.K. Dubey \\ Department of Floriculture and Landscaping, Punjab Agricultural University, Ludhiana, \\ Punjab, India \\ *Corresponding author
}

\section{A B S T R A C T}

\section{Keywords \\ Senescence, Vase life, Shelf life, Pulsing solution, Holding solution}

\section{Article Info}

Accepted: 06 December 2017 Available Online: 10 January 2018
Prolonging the post-harvest life is essential to assure more life of flowers. For prolonging vase life, we should study about the pre-harvest, harvest and postharvest factors of flower crops that ultimately affects the flower life. There are a series of steps involved to prepare flowers for market after harvesting known as post-harvest handling. These steps include: Harvesting, Conditioning, Pre-cooling, Pulsing, Grading, Bunching, Wrapping, Packaging, Storage, Transport and Sale. All the factors that affect post-harvest life of a flower should managed properly to provide optimum condition for plant growth. Different biocide, holding, pulsing solution, growth regulators and different storage temperature are used to promote vase life of lowers.

\section{Introduction}

Flowers have always remained an integral part of human's life and they are very important in the Indian traditional way of life. With increasing standard of living the demand for flowers has increased and meeting these demands depends largely on increasing the production and more importantly proper postharvest handling at all levels. In floriculture industries the post-harvest losses is a major issue and is a worldwide problem. India has exported 22,485.21 MT of floriculture products to the world for the worth of Rs.455.90 crores in 2013-14 (Anonymous, 2014). On the other hand because of their highly perishable nature, flowers are vulnerable to large post-harvest losses. Delayed flower senescence and good presentability are essential for the marketable flowers and are also important goal of researchers. Longer post-harvest life of flowers makes sure that the customers, retailers and final consumers will be satisfied and will return back to purchase more flowers. For increasing the post-harvest life of flowers, we should know about the factors that affect post-harvest life, so that we can provide required condition to plant and hence, postharvest life will be increased. This review provides an overview about the factors affecting post-harvest life of flower crops and ways to increase their life and hence profitability. 
Need for proper post-harvest handling practices

Flowers remain alive even after harvest and continue their metabolic activities causing depletion of carbohydrates, rise in temperature and respiration rates, rapid attack by microorganisms, water stress and increased accumulation of ethylene. All these activities lead to deterioration of the harvested flowers which in turn decreases the longevity of the fresh produce. There arises the need for the appropriate post-harvest handling technologies (Nowak and Rudnicki, 1990). The major factors which lead to the deterioration of the harvested flowers can be classified as:

1) Pre-harvest factors, 2) Harvest factors and

3) Post-harvest factors (Salunkhe et al., 1990 and Bhattacharjee and De, 2003)

\section{Pre-harvest factors affecting flower longevity}

\section{Genetic or inherent makeup}

Post-harvest longevity of flower species and cultivars vary considerably due to differences in their genetic make-up. Anthurium and orchids have longer vase life than rose and Dianthus, whereas lilies have shorter vase life than rose and gerbera (Bhattacharjee and De, 2003). 'Baccara roses' have longer vase life and possesses ability to close their stomata upon cutting than 'golden wave' roses, which possesses short vase life (Mayak et al., 1974)

\section{Environmental factors}

\section{Light}

Light regulate several physiological processes such as photosynthesis, which determine the carbohydrate content of flowers. Flowers containing relatively higher amounts of carbohydrates especially sugars, last longer in the vase. High light intensity causing Scorching of the foliage and flower buds, dropping of leaves and petal senescence where as Low light causes Blueing/ discolouration of petal and Bent Neck in Rose and Stem Bending in Gerbera (Halevy and Mayak, 1979).

\section{Temperature}

Temperature requirement of different crops vary. For example: In rose, the day temp. 20$25{ }^{\circ} \mathrm{C}$ and night temp $16^{\circ} \mathrm{C}$, is required. A difference of $10^{\circ} \mathrm{C}$ day and night temperature is considered ideal for growth and flower production. Low night temperature are advantageous because of low respiration rates at low temperature decreases the utilization of sugars, thereby improving the net accumulation of carbohydrate in the petals. High temperature accelerates the respiration rate and hence, reduces net carbohydrate reserves leading to poor post-harvest life. Too low temperature also causes freezing injury to buds (Halevy and Mayak, 1979).

\section{Humidity}

Optimum level of humidity is required by different crops. For example rose require relative humidity between 60-65 \%. High humidity leads to fungal and bacterial diseases whereas, Low humidity leads to browning of leaf edges, thin leaves. At higher air humidity (90\%) and a $24 \mathrm{~h}$ photoperiod reduces the post-harvest life of several cultivars of Rose. The reduction was attributed to the increased rate of water loss from the leaves due to the failure of stomata to close (Mortenseon and Fjeld, 1998)

\section{Season}

Variation in the longevity of cut flowers due to the seasonal effects has also been reported. Chrysanthemum harvested during hot seasons 
shown longer vase life than those during cold season.

High light intensity associated with higher photosynthetic activity for increased longevity of cut flowers (Singh et al., 2013). Sugar content of petals increases in autumn and decreases slightly towards summer, while chlorophyll intensity increases gradually towards spring and decrease in summer (Celikel and Karacaly, 1995).

\section{Ethylene}

The longevity and quality of cut flowers also depend upon the composition of ambient atmosphere. Ethylene caused the most adverse effects on cut flowers. In carnation, ethylene first produced in gynoecium.

\section{Carbon dioxide}

The atmospheric content of $\mathrm{CO}_{2}$ is very less i.e. $0.03 \%$ (Kumar et al., 2002). It is essential for photosynthesis. $\mathrm{CO}_{2}$ enrichment in greenhouse is advantageous as it improves quality and increases yield and vase life.

\section{Pests}

Flower crops are attacked by various pests and affect the quality of flowers.

\section{Stage of maturity}

Decrease in trend of total and reducing sugar is observed in leaves, whereas increase trend is observed in the total and reducing sugar of corolla from harvest towards senescence.

\section{Harvest factors affecting flower longevity}

The right stage, method and time of harvesting of flowers are of considerable importance to ensure their long vase-life.
Time

Flowers should always be harvested either in morning or evening when temperature is moderate because high temperature leads to faster respiration and excessive water loss.

\section{Method of harvesting}

The stems should be cut with sharp knives or secateurs. Hardwood stems should always be given slanting cut to expose maximum surface area to ensure rapid water absorption. The flowers of dahlia and poinsettia release latex upon cutting.

To overcome such problem, stems should be given a dip in hot water $\left(80-90^{\circ} \mathrm{C}\right)$ for a few seconds.

\section{Stage of harvesting}

Flowers should always be harvested at an optimum stage of maturity. Too immature buds do not open whereas over mature ones wither quickly.

\section{Post-harvest factors affecting vase life}

\section{Temperature}

Opening of flower buds and rate of senescence accelerate at higher temperature. At low temperature, respiration comes down, flower produces less amount of ethylene and multiplication if micro-organism does not takes place at faster rate. The most important metabolic process is respiration that increases with increase in temperature.

\section{Humidity}

Cut flowers should be kept at 90-92\% relative humidity for maintaining turgidity i.e. beneficial for prolonging the vase life of cut flower during post-harvest (Doi et al., 2000). 


\section{Water relations}

The termination of life of the harvested flowers depends on water uptake and transport, water loss and the capacity of the flower tissue to retain its water. Water deficit and wilting develop, when the transpiration exceeds absorption of water. Disruption of water columns in stem vessels by air embolism and resistance to water flow in stems, also develop water deficit. Acidification of water and addition of wetting agent and flower food in the holding solution markedly improve water uptake of cut flowers (Kushal et al., 2013). Vase life of Gladiolus decreases when the conc. Of salts in water approaches $700 \mathrm{ppm}$ and in chrysanthemums and carnation $200 \mathrm{ppm}$ is harmful (Waters, 1968)

\section{Conditioning}

Flowers are kept loosely in big container of water so that air circulates around stem. Main purpose of conditioning is to restore turgidity of cut flowers.

\section{Pre-cooling}

Remove excess field heat either by hydro cooling or refrigeration. Time gap between harvest and pre cooling should be as short as possible. It brings down the respiration rate. For Rose, the Pre-cooling temperature required is $1-3^{0} \mathrm{C}$, Chrysanthemum $-0.5-4{ }^{0} \mathrm{C}$, Carnation- $1{ }^{0} \mathrm{C}$ and for Gladiolus- $4{ }^{\circ} \mathrm{C}$.

\section{Floral preservative}

Floral preservative are chemicals added to water to make flowers last longer.

The marketability of Dutch iris (Iris $\times$ hollandica) cut flowers is limited by their short display life and frequent failure to open fully. Macnish et al., (2010) tested the ability of thidiazuron, a phenyl-urea compound with cytokinin-like activity, to improve iris flower opening and longevity. A postharvest pulse with $0.2-1 \mathrm{mM}$ thidiazuron for $6-24 \mathrm{~h}$ at 0 or $20^{\circ} \mathrm{C}$ extended the vase life of flowers by up to 1.5 days relative to control (0 $\mathrm{mM}$ thidiazuron) stems in water. Salicylic acid prevents ACC-oxidase activity that is the direct precursor of ethylene and decrease ROS (Reactive oxygen species) with increase enzyme antioxidant activity. Also Salicylic acid seems to act by germicide the decrease of bacteria, which block the xylem vessels in the cut region and interfere with the normal flux of water through the stem (Nowak and Rudnicki, 1990). Mei-hua et al., (2008) showed that SA can extending the vase life of cut flowers with decrease ROS and ethylene in Dianthes caryophyllus. Kazemi et al., (2011) suggested that Salicylic acid increases membrane stability by decrease MDA content and ACC- oxidase activity, bacteria populations in vase flower preservative solution of the carnation cut flowers.

\section{Constituents of floral preservatives}

\section{Water}

Acidic water with low $\mathrm{pH}$ (3.0-3.5) decreases microbial growth (Van Doorn, 1995).

\section{Sugar}

Act as additional food source and also improves water balance. Sugars promote microbial growth, so it is usually combined with biocide before use. Among the sugars, glucose (reducing sugar) was found most effective in extending the vase life, followed by fructose (Ichimura et al., 2006).

\section{Biocide}

These are the chemical compound, used to inhibit microbial growth in vase water as well 
as on cut stem. Treatments with some germicides, such as silver nitrate, 8hydroxyquinoline sulphate (HQS) and sodium dichloro-isocyanurate, maintain the hydraulic conductance of the stems of cut roses and extend their vase life (Knee, 2000).

Table.1 Optimum stages of harvesting of different crops: (Nowak and Rudnicki, 1990)

\begin{tabular}{|l|l|l|}
\multicolumn{1}{|c|}{ Name } & \multicolumn{1}{c|}{ Type } & \multicolumn{1}{c|}{ Stage of harvest } \\
\hline Rose & $\begin{array}{l}\text { Red and Pink cultivar } \\
\text { Yellow Cultivar } \\
\text { White Cultivar }\end{array}$ & $\begin{array}{l}\text { First two petal beginning to unfold } \\
\text { Slight earlier than red and pink } \\
\text { Slightly later than red and pink }\end{array}$ \\
\hline Chrysanthemum & $\begin{array}{l}\text { Standard } \\
\text { Spray }\end{array}$ & $\begin{array}{l}\text { Outer petal fully elongated } \\
50 \% \text { of flowers show colour }\end{array}$ \\
\hline Lilium,Iris, Freesia & Coloured buds \\
\hline Carnation & Standard & Paint brush stage \\
\hline Spray & At least two flowers fully open \\
\hline $\begin{array}{l}\text { Gadiolus } \\
\text { Taglia variabilis } \\
\text { Zinnia erecta }\end{array}$ & & $1-5$ bud showing color \\
\hline Tulipa gesneriana & & Fully open flowers \\
\hline
\end{tabular}

Table.2 Different studies on stage of harvest

\begin{tabular}{|c|c|c|c|}
\hline Crop & Material and Methods & Results & Author \\
\hline $\begin{array}{l}\text { Chrysanthemum } \\
\text { cv. Reagen }\end{array}$ & $\begin{array}{l}\mathrm{S}_{1}=\text { ray floret diameter } 1-1.5 \\
\mathrm{~cm} \\
\mathrm{~S}_{2}=\text { buds half open } \\
\mathrm{S}_{3}=3 / 4 \text { open buds }\end{array}$ & $\begin{array}{l}\text { Maximum floret longevity } \\
\text { with } S_{1}\end{array}$ & Singh et al., 2010 \\
\hline Tuberose & $\begin{array}{l}S_{1}=\text { unopened florets } \\
S_{2}=\text { one floret opened } \\
S_{3}=\text { two florets opened } \\
\text { Stem length }: 45,60,75,90 \\
\mathrm{~cm}\end{array}$ & $\begin{array}{l}90 \mathrm{~cm} \text { stem length with one } \\
\text { floret } \\
\text { open stage }\end{array}$ & $\begin{array}{l}\text { Varu and Barad, } \\
2010\end{array}$ \\
\hline $\begin{array}{l}\text { Dendrobium } \\
\text { Orchid } \\
\text { cv.Suree white and } \\
\text { Suree peach }\end{array}$ & $\begin{array}{l}S_{1}=25 \% \text { opened flowers } \\
S_{2}=40 \% \text { opened flowers } \\
S_{3}=50 \% \text { opened flowers } \\
S_{4}=75 \% \text { opened flowers }\end{array}$ & $\begin{array}{l}25 \% \text { opened flowers - } \\
\text { increased } \\
\text { vase life in both varieties }\end{array}$ & Yoode et al., 2013 \\
\hline $\begin{array}{l}\text { Cut Oriental } \\
\text { 'Avacado' } \\
\text { Lily }\end{array}$ & $\begin{array}{l}\mathrm{S}_{1}=\text { Green bud stage } \\
\mathrm{S}_{2}=25 \% \text { colour development } \\
\mathrm{S}_{3}=50 \% \text { colour development } \\
\mathrm{S}_{3}=75 \% \text { colour development }\end{array}$ & $\begin{array}{l}\text { Harvesting of Oriental lily at } \\
\text { green bud stage exhibited } \\
\text { longer vase life (14.33 days) } \\
\text { without abscission of florets } \\
\text { and buds }\end{array}$ & $\begin{array}{l}\text { Chaudhary et al., } \\
2016\end{array}$ \\
\hline
\end{tabular}


Table.3 Types of floral preservatives

\begin{tabular}{|l|}
\hline Pulsing solution \\
\hline Pre- shipment or pre- storage \\
treatment \\
Short duration (16-24 hr) \\
\hline Sugar is main component \\
Higher level of sucrose are used \\
\hline
\end{tabular}

\section{Bud Opening solution}

Solution, in which immature buds of many flowers can be made to open

Lower conc. Of sucrose are used (2-5 $\%)$

\section{Holding/ vase solution}

Hold flower continuously, till termination of their vase life

Level of sucrose is low (0.5- $1 \%)$

Table.4 Storage methods

\begin{tabular}{|c|c|c|}
\hline Storage & Crop & Storage temperature \\
\hline Dry storage & Carnation & 0 to $1^{\circ} \mathrm{C}$ \\
\hline & Chrysanthemum & $1^{\circ} \mathrm{C}$ \\
\hline & Gerbera & $2^{\circ} \mathrm{C}$ \\
\hline & Gladiolus & $4^{\circ} \mathrm{C}$ \\
\hline Wet storage & Rose & 0.5 to $2{ }^{\circ} \mathrm{C}$ \\
\hline & Anthurium & $13^{\circ} \mathrm{C}$ \\
\hline & Carnation & $4^{\circ} \mathrm{C}$ \\
\hline & Chrysanthemum & $4^{\circ} \mathrm{C}$ \\
\hline & Gerbera & $4^{\circ} \mathrm{C}$ \\
\hline & Rose & 2 to $5^{\circ} \mathrm{C}$ \\
\hline & Gladiolus & $4^{\circ} \mathrm{C}$ \\
\hline
\end{tabular}

Singh et al., 2013

Table.5 The flowers which are uniform in colour, stem length and development are grouped together. Internationally recognized grades are as follows

\begin{tabular}{|l|l|c|}
\hline Varieties & Stem length $(\mathbf{c m})$ & Bud size $(\mathbf{c m})$ \\
\hline Large flowered & $60-90$ & $3.0-3.5$ \\
\hline Small flowered & $40-50$ & $2.0-2.5$
\end{tabular}

Table.6 Four grades are used on the basis of overall quality, length of spike and number of florets per spike (Staby et al., 1978)

\begin{tabular}{|l|l|l|}
\hline Grade & Spike length $(\mathbf{c m})$ & No. florets/ spike \\
\hline Fancy & $>107$ & 16 \\
\hline Special & $>96$ to $<106$ & 15 \\
\hline Standard & $>81$ to $<95$ & 12 \\
\hline Utility & $<81$ & 10 \\
\hline
\end{tabular}


Ethylene signaling in petal senescence in carnation (Have and Woltering, 1997)
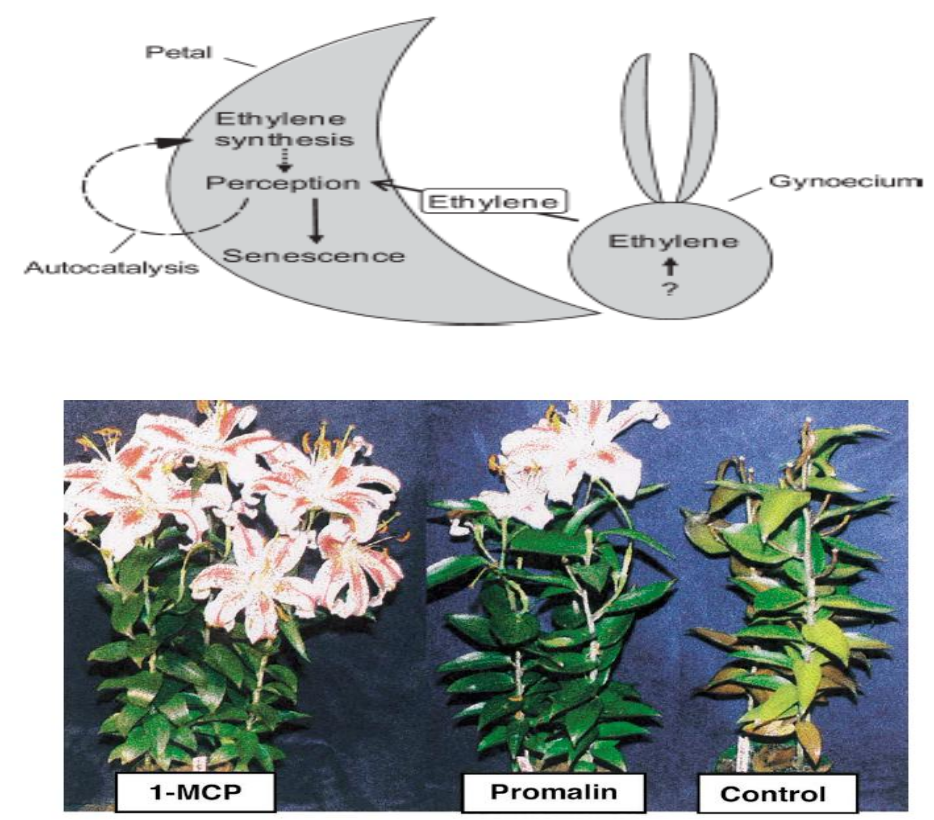

Fig. 3. Effect of 1 -MCP $\left(500 \mathrm{nl} 1^{-1}, 18 \mathrm{~h}, 25^{\circ} \mathrm{C}\right)$ and $180 \mathrm{mg} 1^{-1}$ Promalin pre-treatments on 'Stargazer' Oriental lilies exposed to $5 \mu 11^{-1}$ ethylene for 3 days immediately after harvest, then held in the evaluation room for 16 days.

\section{Use of growth regulators}

Post-harvest life of flowers can be controlled by growth regulators. Water relation changes associated with flower senescence are also influenced by growth regulators.

Auxin does not play much role in improving vase life.

Gibberellin helps in Delaying senescence. It promotes the opening of immature buds in gladiolus. Outer bracts of Gladiolus regulate production of alpha-amylase Saeed et al., 2013 reported that the application of GA3 at 25-50 $\mathrm{mgl}^{-1}$ renders the highest results for improving the vase life and quality of gladiolus cut flowers.

Cytokinins play important role in delaying senescence. Level of cytokinins decreases with ageing. BAP in holding solution delay senescence of Tuberose. Dip treatment of BA increases vase life of Anthurium. Mature coconut water is considered as a rich source of sugar, electrolytes (Jayalekshmi et al., 1986) and growth regulators such as auxin, gibberellins and cytokinin (Mamaril et al., 1986) Agampodi and Jayawardena, 2007 observed that Anthurium cut flower variety wild pink when treated with $50 \%$ Coconut water with $0.23 \% \mathrm{NaOCl}$ shows longest vase life (21 days). Coconut water has been successfully used to increase the post-harvest life of Gerbera (Nair et al., 2000)

Ethylene: a hydrocarbon gas, and commonly known as a ripening hormone induces senescence in many flowers. Some important effects of ethylene are: Sleepiness of petals in carnation, Epinasty in Poinsettia, Abscission of petals or whole flowers, Inhibition or promotion of bud opening in roses. Celikel et al., 2002 studied the effect of 1-MCP and promalin on oriental lily and observed that 1MCP play an important role in preventing post-harvest deterioration of buds and flowers caused by ethylene. 


\section{Storage methods}

\section{Simple refrigerated storage}

It is mostly used in cut flowers. Two types of simple refrigerated storage: In wet storage the stems are stored with their basal portion dipping in water or preservative solution and the temperature is $2-4^{\circ} \mathrm{C}$. Wet storage holds the flower for short duration. Modified atmospheric storage (Dry storage): Sealing of flowers in plastic bags leads to reduction in $\mathrm{O}_{2}$ and increase in $\mathrm{CO}_{2}$ levels due to respiration of tissue (5-7\% $\mathrm{CO}_{2}$ and 1 to $2 \%$ $\mathrm{O}_{2}$ ). Dry storage can be used to hold the flowers for longer duration.

\section{Controlled atmosphere storage}

$\mathrm{CO}_{2}$ and $\mathrm{O}_{2}$ level is controlled. Has a storage chamber where air is continuously circulated and is also released. Low temperature is maintained and RH kept high. Major limitation of CA storage of flowers: Optimum levels of $\mathrm{CO}_{2}$ and $\mathrm{O}_{2}$ required for storage vary for different flowers and hence, different flowers cannot be stored at the same time in the same chamber.

\section{Hypobaric storage}

Storage at low atmosphere pressure i.e. 40$60 \mathrm{~mm} \mathrm{Hg}$ under continuous ventilation and high relative humidity (90-95\%). Major disadvantage: High cost of installation.

\section{Grading}

During sorting, flowers damaged, infested with pest and diseases and defective are discarded. Good flowers are graded according to the bud size and stem length. Uniform buds with stem length of a particular grade range are bunched in 10, 15 or 20 number. Grading is normally done on the basis of flower quality judged by bud or bloom regularity, stem length and straightness. The grades prevailing in roses and gladioli in international trade are given below.

\section{Roses}

The flowers which are uniform in colour, stem length and development are grouped together. Internationally recognized grades are as follows:

\section{Gladiolus}

Four grades are used on the basis of overall quality, length of spike and number of florets per spike (Staby et al., 1978).

While grading care should be taken to discard the bruised, broken, diseased and insect damaged flowers. Same grade flowers are bunched together and wrapped with cellophane paper to improve the display value.

\section{Packaging}

Package ensures quality maintenance during transport and storage. Package should withstand shocks, drops, vibration, compression and refrigeration during shipping and storage.

Package standards vary with flower crops, cultivars, mode of transport, storage and market outlet to meet the regulation of importing countries. Package is considered as silent salesman and it influences the consumers at a sub-conscious level, evoking an image of quality and stimulating the desire to buy.

The inner layer of package should also provide cushioning effect to the flowers. Some of the packaging material commonly used are cellophane paper, newspaper, fluted card board paper, polypropylene, 
polyethylene, craft paper and tissue paper either in the form of sleeves, cones, cups or simple wrapping over flowers. Corrugated cardboard boxes are commonly used for packaging of flowers.

Package should be labeled mentioning source, crop, variety, grade and number of flowers or bunches with handling tip. Singh et al., in 2007 reported that Polypropylene packing in cold storage can keep the gladiolus spikes up to 10 days. Dastagiri et al., (2014) observed that Ornithogalum spikes can be best stored up to 3 days at $4^{\circ} \mathrm{C}$ in modified atmosphere packaging with cellophane.

It is necessary to study the post-harvest factors; so that we can maintain these factors according to crop demand and post-harvest life can be improved. Training for flower packing and transportation should be given to farmers.

Establishing cold storage after harvesting, flower senescence is a necessary evil that cannot be completely checked but can be delayed or partially controlled by using of Anti-ethylene compound and several package practices.

\section{References}

Anonymous. 2014. APEDA. 2013-2014. www.apeda.gov.in

Anonymous. 2014. NHB Indian Horticulture Database - 2013, www.nhb.gov.in

Bhattacharjee, S. K. and De, L. C. 2003. Advanced Commercial Floriculture. Pp.180-190. Aavishkar Publishers, Rajsthan.

Celikel, F. G., Dodge, L. L. and Reid, M. S. 2002. Efficacy of 1-MCP and Promalin for extending the post-harvest life of oriental lilies (Lilium $X$ 'Mona Lisa' and 'Stargazer'). Scientia Horticulturae. 93: 149-155.
Celikel, F.G. and Karacaly, Y. 1995. Effect of preharvest factors on flower quality and longevity of cut carnations (Dianthus caryophyllus L.). Acta Horticulturae. 405: 156-163

Chaudhary, N., Kumar, R., Sindhu, S. S., Saha, T.N., Arora, A., Sharma, R. R., Sarkar, S. K., Kadam, G. B. and Girish, K. S. 2016. Journal of Applied and Natural Science. 8: 1286 - 1289.

Dastagiri, D., Sharma, B. P. and Dilta, B. S. 2014. Effect of wrapping materials and cold storage durations on keeping quality of cut flowers of Ornithogalum Thyrsoides Jacq. Indian Journal of Applied Research. 7: 4-6.

Doi, M., Y. Hu, and H. Imanishi. 2000. Water relations of cut roses as influenced by vapor pressure deficits and temperatures. J. Japan. Soc. Hort. Sci. 69: 584-589.

Halevy, A. H. and Mayak, S. 1979. Senescence and post-harvest physiology of cut flowers. Part I. Hort. Rev (ed. Janick, J.) 1: 204-236.

Ichimura, K., M. Kishimoto, R. Norishikori, Y. Kawabata and K.Yamada. 2005. Soluble carbohydrates and variation in vase life of cut rose cultivars 'Delilah' and 'Sonia'. Journal of Horticulture Science and Bio technology. 80: 280286.

Kazemi, M., Hadavi, E. and Hekmati, J. 2011. Role of salicylic acid in decreases of membrane senescence in cut carnation flowers. Journal of Agricultural Technology. 7: 1417-1425.

Knee, M., 2000. Selection of biocides for use in floral preservatives. Postharvest Biology and Technology. 18: 227-34.

Kumar, N., Dubey, R K., Misra, R L. and Misra, S. 2002. Pre and Post-harvest factors influencing cut flower longevity. In: Floriculture Research Trend in India. Indian Society of Ornamental Horticulture, IARI, New Delhi. Pp. 1- 
12.

Macnish, A. J., Cai-Zhong, J. and Reid, M. S. 2010. Treatment with thidiazuron improves opening and vase life of iris flowers. Post-harvest Biology and Technology. 56: 77-84.

Mayak, S., Halevy, A. H., Sagie, S., Yosef, A. B. and Bravdo, B. 1974. The water balance of cut rose flowers. Physiology Plants. 32: 15-22.

Mei-hua, F., Jian-xin, W., Shil, S. H. I. G. and Fan, L. 2008. Salicylic Acid and 6-BA Effects in Shelf-life Improvement of Gerbera jamesonii Cut Flowers. Anhui Agricultural Science Bulletin.

Mortensen, M.L. and Fjeld, T. 1998. Effects of air humidity, lighting period and lamp typeon growth and vase life of roses. Scientia Horticulturae. 73: 229237.

Nair, S. A., Sivasamy, N., Attri, B. L. and Sharma, T. V. R. S. 2000.Effect of natural and chemical floral preservatives on vase life of cut Gerbera, A comparative study. Indian Coconut Journal. 31:29-31.

Nowak, J. and Rudniki, R M. 1990. Postharvest handling and storage of cut flowers, florist green and potted plants. Timber Press, Portland.

Saeed, T., Hassam, I., Abbasi, N. A. and Jilani, G. 2014. Effect of gibberlic acid on vase life and oxidative activities in senescing cut gladiolus flowers. Plant Growth Regul. 72: 89-95.

Salunkhe, D. K., Bhatt, N. R and Desai, B. B. 1990. Postharvest Biotechnology of Flowers and Ornamental plants. Naya Prakash, Calcutta.

Singh, A., Kumar, J. and Kumar, P. 2007. Effect of different packaging films and cold storage durations on keeping quality of gladiolus cut spikes. J. Orn. Hort. 10: 235-239

Singh, K., Singh, R., Kumar, R and Chawla, N. 2010. Effect of harvesting stages and BAP on post storage keeping quality of cut stems of Chrysanthemum (Dendranthema grandiflora). Journal of Ornamental Horticulture 13: 233-236.

Singh, Kushal, Kumar, Gunjeet, Saha, T. N. and Kumar, Ramesh. 2013. PostHarvest Technology of Cut Flowers. Pp. 26-28. Venus Printers and Publishers, New Delhi.

Ten, H. A. and Woltering, E. J. 1997. Ethylene biosynthetic genes are differentially expressed during carnation (Dianthus caryophyllus L.) flowers senescence. Plant Molecular Biology. 34: 89-97.

Van Doorn, W. G. 1995. Vascular occlusion in cut rose flowers: A survey. Acta Horticulturae. 405: 58-66.

Varu, D. K. and Barad, A. V.2010. Effect of stem length and stage of harvest on vase life of cut flowers in tuberose (Polianthes tuberosa L.) cv. Double. Journal of Horticultural Science. 5: 4247.

Waters W E.1968. Relationship of water salinity and fluorides to keeping quality of chrysanthemum and gladiolus cut flowers. Proceedings of American Society of Horticultural Science. 92: 633-640.

Yoodee, S., Chanjirakul, K. and Obsuwan, K. 2013. Effect of different maturity stages on the display life of cut Dendrobium orchids. Acta Horticulturae. 970: 251254.

\section{How to cite this article:}

Jagreeti Gupta and Dubey, R.K. 2018. Factors Affecting Post-Harvest Life of Flower Crops. Int.J.Curr.Microbiol.App.Sci. 7(01): 548-557. doi: https://doi.org/10.20546/ijcmas.2018.701.065 